\title{
MORPHOMETRY OF ORBIT IN SOUTH INDIAN DRY SKULLS - DIMEN- SIONS OF ORBITAL ROOF AND FLOOR
}

\author{
Mekala D ${ }^{* 1}$, Shubha $\mathbf{R}^{2}$, Vimala $\mathbf{V}^{3}$
}

${ }^{* 1}$ Assistant professor, Department of Anatomy, Coimbatore Medical College, Coimbatore.

${ }^{2}$ Professor \& HOD, Department of Anatomy, Kempegowda Institute of Medical Sciences, Bangalore.

${ }^{3}$ Assistant professor, Department of Anatomy, Coimbatore Medical College, Coimbatore.

\section{ABSTRACT}

Background: The human orbit is a complex anatomic region. Each of its four bony walls has its own unique features and is perforated by a number of fissures and foramina that carry important nerves and blood vessels. This is an anatomical region which is of clinical \& surgical interest to many disciplines like ophthalmology, oral and maxillofocial surgery and neurosurgery. This morphometric study is undertaken to provide the normal reference values of roof and floor of the orbit in south Indian population.

Materials and Methods: The study was done on 200 skulls (105 males and 95 females). The length of orbital roof and floor were measured by using manual vernier caliper. All the data obtained were tabulated and analysed statistically by computing descriptive statistics like mean, standard deviation and range. Mann-Whitney test was done to find out the statistical significance of all parameters of orbits, with respect to gender and side (right and left side).

Results: The results showed that the length of orbital roof and floor were significantly larger in males than in females. There were no significant differences in between the right and left side orbits.

Conclusion: This study has compared the orbital roof and floor length between the genders and between the sides of the skulls. The prior knowledge of the orbital parameters may help to restore the normal anatomy of the orbit during maxillofacial and reconstructive surgeries.

KEY WORDS: Dry skull, orbital roof, orbital floor.

Address for Correspondence: Dr. Mekala D, Assistant professor, Department of Anatomy, Coimbatore Medical College, Coimbatore, Tamilnadu, India. E-Mail: mekalavijayanand@gmail.com

Access this Article online

Quick Response code

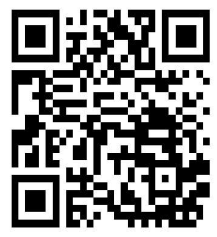

DOI: $10.16965 /$ ijar.2017.494

Journal Information

International Journal of Anatomy and Research

ICV for 2016 ISSN (E) 2321-4287 | ISSN (P) 2321-8967

90.30 https://www.ijmhr.org/ijar.htm DOI-Prefix: https://dx.doi.org/10.16965/ijar

Article Information

Received: 02 Nov 2017

Peer Review: 02 Nov 2017

Revised: None
Accepted: 01 Dec 2017

Published (O): 05 Jan 2018

Published (P): 05 Jan 2018

\section{INTRODUCTION}

The human orbit is a complex anatomic region. Each of its four bony walls has its own unique features and is perforated by a number of fissures and foramina that carry important nerves and blood vessels [1].

Each orbital cavity essentially is intended as a socket for eye-ball and also contains associated muscles, vessels, nerves, lacrimal apparatus, fascial strata and soft pad. In a nutshell it lodges the visual apparatus. This is an anatomical region which is of clinical \& surgical interest to many disciplines like ophthalmology, oral and maxillofocial surgery and neurosurgery [2].

Several diseases including trauma, inflammation, infections, and tumors can involve the orbital cavity. In particular situations, surgeries in the orbit, for example, orbital decompression, 
enucleation, exentration, optic nerve decompression and vascular ligation, have an essential role. However, to avoid injuries to the important structures in the orbit, precise knowledge of the anatomy of the orbit is indispensable [3].

Study of the Anatomy of the orbit allows the anaesthetist to understand how to insert needles within the orbit [4].

This morphometric study is undertaken to provide the normal reference values of roof and floor of the orbit in south Indian population.

\section{MATERIALS AND METHODS}

200 skulls were collected from the Anatomy Department of Kempegowda Institute of Medical Sciences and Bangalore Medical College, Bangalore, Karnataka, India and also from the 1st year medical students of Kempegowda Institute of Medical Sciences. Based on the morphology, they were differentiated into 105 male and 95 female skulls.

The roof length of the orbit was measured from the midpoint of the upper margin of the orbit to the apex of the orbit (optic foramen OF) using a thick strip of paper. In the same way the length of floor of the orbit was measured from the midpoint of lower margin to the apex of the orbit. The length of the paper was then measured with vernier caliper (Fig. 1).

Fig. 1: Measurement of Roof Length (RL) and Floor Length (FL).

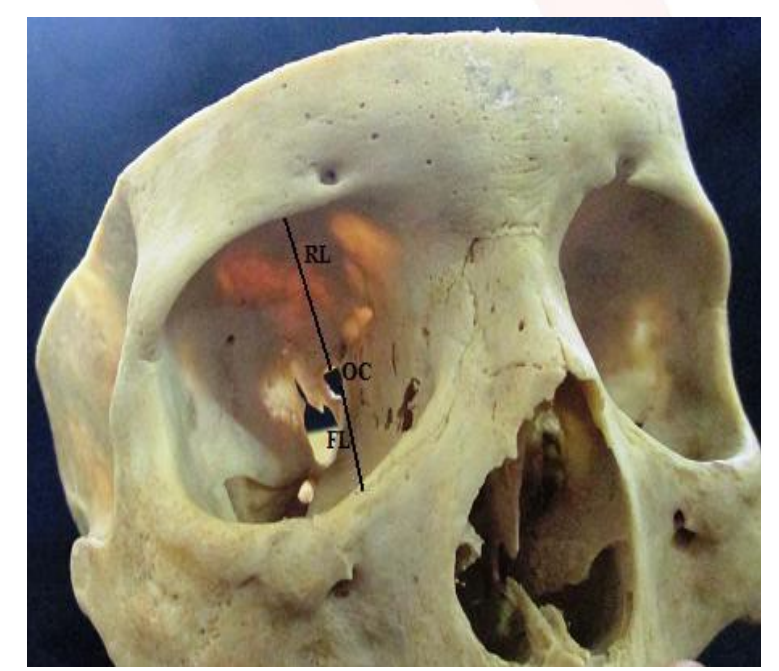

Oc- optic canal, RL- Roof length, FL - Floor length

The data obtained were tabulated and analysed statistically by computing descriptive statistics like mean, standard deviation and range. MannWhitney test was done to find out the statistical significance of all parameters of orbits, with respect to gender and side (right and left side). The results were considered significant when $p<0.05$ and was considered highly significant when $p<0.001$.

The Statistical analysis was done using Statistical Package for Social Sciences (SPSS) software and Microsoft word excel were used to generate graphs and tables.

\section{RESULTS}

The highest value of the roof length was same in both the genders $(5.9 \mathrm{~cm})$, whereas the lowest value was noted in the female orbits as $4.2 \mathrm{c} . \mathrm{m}$. In the same way the highest value of the floor length was same in both the genders $(5.5 \mathrm{~cm})$, and the lowest value of $3.5 \mathrm{~cm}$ was noted in the female orbits. When the mean values of roof and floor length between the two genders were compared the z-value was highly significant $(P<0.001)$.

Graph 1: Comparison of roof and floor length between the genders.

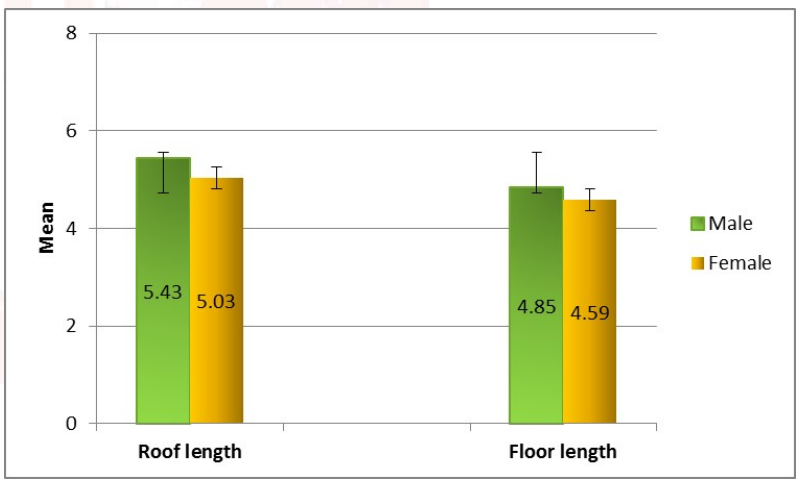

Table 1: Comparison of length of roof and floor between male and female orbits in skulls.

\begin{tabular}{|c|c|c|c|c|c|c|c|}
\hline parameter & Gender & Mean & Std dev & $\begin{array}{l}\text { SE of } \\
\text { mean }\end{array}$ & \begin{tabular}{|c|} 
Mean \\
difference
\end{tabular} & Z & P-Value \\
\hline \multirow{2}{*}{ Roof length } & Male & 5.15 & 0.3 & 0.02 & \multirow{2}{*}{0.405} & \multirow{2}{*}{-11.921} & \multirow{2}{*}{$<0.001^{*}$} \\
\hline & Female & 4.75 & 0.26 & 0.02 & & & \\
\hline \multirow{2}{*}{$\begin{array}{l}\text { Floor } \\
\text { length }\end{array}$} & Male & 4.85 & 0.31 & 0.02 & \multirow{2}{*}{0.265} & \multirow{2}{*}{-7.82} & \multirow{2}{*}{$<0.001^{*}$} \\
\hline & Female & 4.59 & 0.3 & 0.02 & & & \\
\hline
\end{tabular}

When the mean values of length of roof and floor were compared, there were no significant differences between the two sides.

Table 2: Comparison of length of roof and floor between right and left side orbits in overall skulls.

\begin{tabular}{|c|c|c|c|c|c|c|c|}
\hline parameter & Side & Mean & Std dev & $\begin{array}{c}\text { SE of } \\
\text { mean }\end{array}$ & $\begin{array}{c}\text { Mean } \\
\text { difference }\end{array}$ & Z & P-Value \\
\hline \multirow{2}{*}{ Roof } & Right & 4.95 & 0.35 & 0.02 & \multirow{2}{*}{-0.028} & -0.715 & 0.475 \\
\cline { 2 - 6 } & Left & 4.98 & 0.35 & 0.02 & & & \\
\hline \multirow{2}{*}{ Floor } & Right & 4.72 & 0.33 & 0.02 & \multirow{2}{*}{-0.002} & -0.02 & \multirow{2}{*}{0.984} \\
\cline { 2 - 5 } & Left & 4.73 & 0.33 & 0.02 & & & \\
\hline
\end{tabular}




\section{DISCUSSION}

Orbital fractures are observed in more than $40 \%$ of maxillofacial injuries and thus represent the most common fractures of the midface [5].

Understanding its structure proportion and mechanical function is vital in ophthalmology, oral maxillofacial surgery and neurosurgery [6].

The prior knowledge of orbital parameters may help for better outcome of surgical procedures.

The results of present study are compared with the previous studies.

Table 3: Comparison of roof length between the two genders in the present study with that of previous studies.

\begin{tabular}{|c|c|c|c|}
\hline Authors & Male & Female & $\mathrm{P}$ \\
\hline Thanasil Huanmanop et al [3] & Right -4.52 & 4.38 & $<0.05$ \\
\cline { 2 - 4 } & Left -4.54 & 4.43 & $>0.05$ \\
\hline $\begin{array}{c}\text { Yongrong ji et al[7] } \\
\text { (CT scan) }\end{array}$ & 5.293 & 5.089 & 0.003 \\
\hline $\begin{array}{c}\text { Bryan C. Mendelson et al[8] (CT } \\
\text { scan) }\end{array}$ & 5.45 & 5.14 & 0.004 \\
\hline Present study & 5.15 & 4.75 & $<0.001$ \\
\hline
\end{tabular}

Table 4: Comparison of roof length of the orbit between the two sides in the present study with that of previous skull studies.

\begin{tabular}{|c|c|c|c|}
\hline Authors & Right & Left & P \\
\hline Jeremiah Munguti [9] & 5.29 & 5.31 & 0.927 \\
\hline Thanasil Huanmanop et al [3] & 4.45 & 4.48 & $>0.05$ \\
\hline Yongrong ji et al [7] (CT scan) & 5.167 & 5.184 & 0.115 \\
\hline Present study & 5.24 & 4.23 & 0.695 \\
\hline
\end{tabular}

In contrast to our results, Thanasil Huanmanop et al [3] have reported that the roof length of right side orbits in females was significantly shorter than that of males. And there was no significant difference in the roof length between the left side orbits of males and females.

These differences could be due to variations in the methodology.

The reasons of lower values of the roof length compared to the results of the present study could be because of racial differences as their study population is different and also relatively smaller sample size $(n=50)$ in their study.

Yongrong ji et al [7] and Bryan C. Mendelson et al [8] studied the orbital parameters in CT scans. The results of their study are similar to that of the present study which shows that the roof length is larger in males when compared to females.
The variations in the values of roof length may be because of variation in the studied population, variations in the methodology and also smaller sample size in their study.

Previous studies have reported that there were no significant differences in roof length of the orbit between the two sides, which correlates with the results of present study.

Table 5: Comparison of floor length between the two genders in the present study with that of previous studies.

\begin{tabular}{|c|c|c|c|}
\hline Authors & Male & Female & $\mathbf{P}$ \\
\hline $\begin{array}{c}\text { Thanasil Huanmanop et } \\
\text { al [3] }\end{array}$ & Right -4.69 & 4.61 & $>0.05$ \\
\cline { 2 - 4 } & Left -4.65 & 4.53 & $>0.05$ \\
\hline $\begin{array}{c}\text { Yongrong ji et al [7] (CT } \\
\text { scan) }\end{array}$ & 4.793 & 4.618 & 0.01 \\
\hline $\begin{array}{c}\text { Bryan C. Mendelson et } \\
\text { al [8] }\end{array}$ & 5.4 & 5.16 & 0.03 \\
\hline Present study & 4.85 & 4.59 & $<0.001$ \\
\hline
\end{tabular}

In Thanasil Huanmanop et al [3] study there is no significant difference in floor length between the genders, which is contrary to present study.

And there is a minimal difference in the values of previous study and the present study. This could be due to racial differences and also they have not compared the floor length between the genders irrespective of side.

Yongrong ji et al [7] and Bryan C. Mendelson et al [8] have reported in their CT scan studies that the floor length of orbits in males is significantly larger than in females, which correlates with the present study.

Table 6: Comparison of floor length of the orbit between the two sides in the present study with that of previous skull studies.

\begin{tabular}{|c|c|c|c|}
\hline Authors & Right & Left & P \\
\hline Jeremiah Munguti 2012 [9] & 5.47 & 5.48 & 0.927 \\
\hline Thanasil Huanmanop et al 2007 [3] & 4.59 & 4.65 & $>0.05$ \\
\hline Yongrong ji et al [7] (CT scan) & 4.685 & 4.7 & 0.107 \\
\hline Present study & 4.73 & 4.72 & 0.984 \\
\hline
\end{tabular}

Both the previous studies have reported that there was no significant difference in the floor length between the two sides.

In Jeremiah Munguti et al [9] study the values are higher than the present study. These differences may be due to variation in the population studied and also due to difference in the methodology of recording. 
Human face carries information that allows the identification of a single person. Additionally, reference anthropometric data of the orbital region are necessary for multiple diagnostic and forensic procedures (evaluations of traumas, chromosomal and single gene alterations, teratogenic - induced conditions such as fetal alcohol syndrome, facial reconstruction, etc). [10]

\section{CONCLUSION}

This study has compared the orbital roof and floor length between the genders and between the sides of the skulls. Orbital fractures are commonly seen with midfacial trauma.

The floor of the orbit is frequently involved either in isolation as a so called 'pure' type of blow out fracture or more commonly as an impure fracture in association with other fractures in zygomatic area. This is because, the infra orbital groove \& canal weaken the already thin $(0.5 \mathrm{~mm}$ thickness) floor further [2]. The prior knowledge of orbital parameters may help to restore the normal anatomy of orbit during maxillofacial and reconstructive surgeries. We also planned to extend the study to measure the other orbital parameters.

\section{ABBREVIATIONS}

OF- Optic Foramen

Std dev- Standard Deviation

SE-Standard Error

\section{Conflicts of Interests: None}

\section{REFERENCES}

[1]. Andy C. O. Cheng, Peter W. Lucas, Hunter K. L. Yuen, et al. Surgical Anatomy of the Chinese orbit. Ophthalmic Plastic and Reconstructive Surgery 2007; 24(2): 136-141

[2]. Patnaik V.V.G., Bala Sangu, Singla Rajan K. Anatomy of the Bony Orbit- Some Applied Aspects. J Anat. Soc. India. 2001; 50(1): 59-67.

[3]. Thansil Huanmanop, Sithiporn Agthong, Vilai Chentanez. Surgical Anatomy of fissures and foramina in the orbits of Thai adults. J Med Assoc Thai 2007; 90(11): 2383-2390.

[4]. R. W. Jhonson. Anatomy for ophthalmic anaesthesia. British Journal of Anaesthesia 1995; 75: 80-87.

[5]. G.Rameieri, MC Spada, SD Bianchi, et al. Dimensions and volumes of the orbit and orital fat in posttraumatic enophthalmos. Dentomaxillofacial Radiology 2000; 29: 303-311.

[6]. Ebeye O.A, Otikpo O. Orbital index in Urhobos of Nigeria. IOSR Journal of Dental and Medical Sciences 2013; 8(2): 51-53.

[7]. Yongrong Ji, Zanqun Qian, Yang Dong, et al. Quantitative morphometry of the orbit in Chinese adults based on a yhree-dimensional reconstruction method. J. Anat 2010; 217: 501-506

[8]. Bryan C. Mendelson, Winfield Hartley, Mark Scott, et al. Age-Related changes of the orbit, and midcheek, and the implications for facial rejuvenation. Aesth. Plast. Surg 2007; 30:1-6.

[9]. Jeremiah Munguti, Pamela Mandela, Fawzia Butt. Referencing orbital measures for surgical and cosmetic procedures. Anatomy Journal of Africa 2012; 1(1): 40-45.

[10]. Chiarella Sforza, Gaja Grandi, Francesca catti. Ageand sex-related changes in the soft tissue of the orbital region. Forensic Science International 2009; $1-14$.
How to cite this article:
Mekala D, Shubha R, Vimala V. MORPHOMETRY OF ORBIT IN
SOUTH INDIAN DRY SKULLS - DIMENSIONS OF ORBITAL ROOF
AND FLOOR. Int J Anat Res 2018;6(1.1):4876-4879. DOI: 10.16965/
ijar.2017.494 